\title{
Türkçe Yeterlik Sınavı'nın (TYS) Uluslararası Geçerliğe Sahip Bazı Dil Yeterlik Sınavlarıyla İçerik Açısından Karşılaştırılması*
}

\section{Comparison of The Content of Turkish Proficiency Exam (TPE) and Some Language Qualification Exams with International Language Proficiency Exams}

\author{
Murat ŞENGÜL ${ }^{1} \oplus$, Serkan DEMIREL ${ }^{2}$
}

* Bu makale, birinci yazarın danışmanlığında ikinci yazar tarafından hazırlanan "Türkçe Yeterlik Sınavı́nın (TYS) Uluslararası Geçerliğe Sahip Bazı Dil Yeterlik Sınavlarıyla Karşılaştırılması" adı yüksek lisans tezinden özetlenerek hazırlanmıştır.

\section{${ }^{1}$ Murat Şengül (Doç. Dr.)}

Nevşehir Hacı Bektaș Veli Üniversitesi, Eğitim

Fakültesi, Türkçe ve Sosyal Bilimler Eğitimi

Bölümü, Türkçe Eğitimi Anabilim Dalı,

Nevşehir, Türkiye

E-posta: muratsengul@nevsehir.edu.tr

ORCID: 0000-0003-2163-9420

${ }^{2}$ Sorumlu yazar/Corresponding author: Serkan Demirel (Doktora Öğrencisi),

Gazi Üniversitesi, Eğitim Bilimleri Enstitüsü,

Türkçe ve Sosyal Bilimler Anabilim Dalı, Yabancı

Dil Olarak Türkçenin Öğretimi Bilim Dalı,

Ankara, Türkiye

E-posta: muallimserkan@hotmail.com

ORCID: 0000-0002-5039-0372

Başvuru/Submitted: 07.08.2021

Revizyon Talebi/Revision Requested:

08.09.2021

Son Revizyon/Last Revision Received:

14.09.2021

Kabul/Accepted: 15.09 .2021

Online Yayın/Published Online: 26.11.2021

Atıf/Citation: Sengul, Murat ve Demirel, Serkan. "Türkçe Yeterlik Sınavi'nın (TYS) Uluslararası Geçerliğe Sahip Bazı Dil Yeterlik Sınavlarıyla İçerik Açısından Karşılaştııılması." Türkiyat Mecrmuası-Journal of Turkology 31, 2 (2021): 573-598.

https://doi.org/10.26650/iuturkiyat.979947

\section{ÖZ}

Bu araştırmanın amacı, Türkçe Yeterlik Sınavı'nı (TYS) uluslararası alanda uygulanan dil yeterlik sınavlarıyla içerik (sınavların hangi becerilere göre hazırlandığı, sınavlarda hangi soru çeşitlerine yer verildiği) yönünden karşılaştırıp TYS'nin niteliksel görünümünü tespit etmektir. Araştırmanın veri kaynağı Yunus Emre Enstitüsü tarafından yapılan Türkçe Yeterlik Sınavı (TYS) ve uluslararası alanda yapılan dil yeterlik sınavlarıdır. ÖSYM'nin eşdeğerlik tablosunda yer alan bu sınavlar İngilizce için CPE, CAE, TOEFL iBT, PTE Akademik; Almanca için TestDaF, DSD II, telc Deutsch ve Goethe-Zertifikat; Fransızca için DELF \& DALF, İspanyolca için DELE, İtalyanca için CELI, Rusça için TORFL'dır. Veri kaynakları içerik analizi tekniğiyle incelenmiştir. Elde edilen verilere göre, TYS ve diğer dil yeterlik sınavlarının tamamının dört beceriye (dinleme, konuşma, okuma, yazma) göre hazırlandığı, bununla beraber bazı dil yeterlik sınavlarında dil bilgisi bölümünün ve bütünleşik becerilerin ölçüldüğü bölümlerin de bulunduğu saptanmıştır. Soru çeşidi açısından TYS'deki soru çeşitlerinin diğer dil yeterlik sınavlarındaki sorularla benzerlik taşıdığı ancak diğer dil yeterlik sınavlarında sorulup TYS'de bulunmayan soru çeşitlerinin de olduğu belirlenmiştir.

Anahtar kelimeler: TYS, Dil Yeterlik Sınavı, Avrupa Ortak Öneriler Çerçevesi (AOÖÇ), Dil Becerileri, Sınav İçerikleri

\section{ABSTRACT}

The aim of this research is to compare the Turkish Proficiency Exam (TPE) with the language proficiency exams applied internationally in terms of content (what skills the exams are prepared for, what types of questions are included in the exams) and to determine the qualitative view of TPE. The data source of the research is the Turkish Proficiency Exam (TPE) administered by Yunus Emre Institute and the language proficiency exams held in the international arena. These exams are in the equivalence table of ÖSYM (Republic of Turkey Measurement Selection and Placement Center). These exams are CPE, CAE, TOEFL iBT, PTE Academic for English; TestDaF, DSD II, telc Deutsch and GoetheZertifikat for German; DELF \& DALF for French, DELE for Spanish, CELI for Italian, TORFL for Russian. Data sources were analyzed by content analysis technique. 
According to the data obtained, It has been determined that all of the TPE and other language proficiency exams are prepared according to four skills (listening, speaking, reading, writing), however, some language proficiency exams also have sections that measure grammar and integrated skills. In terms of question type, TPE and other language proficiency exams are similar in terms of question types, but there are also question types that are found in other language proficiency exams but not in TPE.

Keywords: TPE, Language Proficiency Exam, CEFR, Language Skills, Contents of Exam

\section{EXTENDED ABSTRACT}

The aim of this research is to compare the Turkish Proficiency Exam (TPE) with the language proficiency exams administered internationally in terms of content and to determine the qualitative appearance of TPE. The data sources of the research consist of The Turkish Proficiency Exam (TPE) conducted by Yunus Emre Institute and internationally held language proficiency exams. These exams which are included in the equivalency table of ÖSYM are CPE, CAE, TOEFL iBT, PTE Academic for English; TestDaF, DSD II, telc Deutsch and GoetheZertifikat for German; DELF \& DALF for French, DELE for Spanish, CELI for Italian, and TORFL for Russian. Data sources were analyzed by the content analysis technique.

In the context of the data obtained, TPE and other language proficiency exams were prepared according to four skills. However, some language proficiency exams also have a grammar section, and sections where integrated skills are measured. The types of questions in the reading, listening, writing and speaking exams of TPE are the same as those in other exams. In the reading section, graphic reading question type presented originality. There are types of questions asked in other language proficiency exams that are not present in the TPE. These types of questions in the reading exam are sentence completion, paragraph creation, paragraph completion, matching, summarizing the text, completing the text, short-answer questions, and integrated skills questions. In the listening exam, the questions are follow-up text questions, short-answer questions, and integrated skills questions. In the writing exam, they are correcting errors in the text, summarizing, integrated skills questions, graphic interpretation, and text reconstruction questions. In the listening exam, the questions are follow-up text questions, short-answer questions, and integrated skills questions. In the writing exam, they are correcting errors in the text, summarizing, integrated skills questions, graphic interpretation, and text reconstruction questions. In the speaking test, these questions are talking about a picture or a photograph, repeating a sentence, evaluating data, making a phone call, interpreting a video, speaking a sentence with an emotional tone (meta language), persuading, giving a radio talk, integrated skills questions, and talk to partner. There are no sample solutions in the reading exam of the TPE. In the TPE, listening texts are played once, and in the listening exams of other language proficiency exams, the texts in certain tasks are played for a second time. Written phonetic transcription of listening texts are included in the sample exams of TestDaF, DSD II, telc Deutsch B2, telc Deutsch C1, telc Deutsch C2, Goethe-Zertifikat B2, GoetheZertifikat C1, Goethe-Zertifikat C2 GDS, DELF B2, DALF C1, DALF C2, DELE Nivel B2, 
DELE Nivel C1, DELE Nivel C2, TORFL Level 2, TORFL Level 3, TORFL Level 4, but the phonetic transcription of texts in the sample exams of TPE, CPE, CAE, PTE Academic, TOEFL iBT, CELI 3, CELI 4, CELI 5 are not found. There are 2 tasks in the writing exam of the TPE. In the TPE speaking exam, the candidate is given a 2/3-minute preparation period. The number of candidates taking the speaking exam varies according to the exams. There is no grammar section in the TPE. The grammar section is formed either as an independent section in some of the language proficiency exams or as a separate section within the reading and listening exams.

Considering these findings, the following suggestions are included in the study: The variety of questions in the TPE can be increased. Sentence completion, paragraph creation, paragraph completion, matching, summarizing the text, completing the text, short-answer questions, integrated skills questions in reading exams; follow-up text questions, short answer questions, integrated skills questions in listening exams; correcting errors in the text, summarizing, integrated skills questions, graphic interpretation, text reconstruction questions in writing exams; picture, photo, video interpretation, sentence repetition, data evaluation, telephone conversation, radio speeches, talk to partner, meta language skills questions in speaking exams can be included in the TPE in similar or different ways. As in other language proficiency exams, presenting the students with a sample solution can be practiced in the TPE. The texts in the listening test can be played for a second time. The written form of the listening texts, the phonetic transcription can be shared together with sample questions. The preparation time for the speaking test can be increased. Depending on the content of the questions, the preparation time can be equal to the exam time. It can be 15 minutes of preparation time, and 15 minutes of exam time. Sample answer texts given to these questions can be shared as well as the questions related to the writing exam. 


\section{Giriş}

Türkçe Yeterlik Sınavı'nı (TYS) uluslararası alanda uygulanan dil yeterlik sınavlarıyla içerik yönünden karşılaştırılmasına dayanak oluşturan kavramsal çerçeve için aşağıdaki konu başlıklarına yer verilmiştir:

\subsection{Dil Becerilerinin Ölçümü}

Dil becerileri tanımlayıcıları 2001 yılında yayınlanan Avrupa Ortak Öneriler Çerçevesi’nde (AOÖÇ) yer almaktadır. Bu tanımlayıcılar hem öğretim basamakları hem de ölçmedeğerlendirme için kılavuz özelliktedir. Dört temel dil becerisi vardır. Bunlar okuma, dinleme, yazma ve konuşmadır. Fakat süreç içerisinde dört temel dil becerisi iletişimin karmaşık yapısında yetersiz kaldığından, bunun yerine iletişimsel dil faaliyetlerinin ve stratejilerinin uygulanmasının önemi AOÖÇ'de bahsedilmektedir. AOÖÇ’nin önerdiği yapılanma, anlamın birlikte inşa edildiği etkileşime dayanan gerçek hayattaki dil kullanımına yakındır. ${ }^{1} \mathrm{Bu}$ nedenle iletişimsel dil faaliyetlerinde algılama, üretim, etkileşim, aracılık kavramları vardır. İletişimsel dil faaliyetlerindeki temel dil becerileri ve CEFR 2001, CEFR 2018, OBM 2009, AOÖÇ 2013’teki adlandırılmaları aşağıda tablolaştırılmıştır.

Tablo 1. İletişimsel Dil Faaliyetlerinin Adlandırılmaları ve Etkinliklere Karşılık Gelen Dört Beceriye İlişkin Bilgiler

\begin{tabular}{|c|c|c|c|c|}
\hline \multicolumn{2}{|c|}{ Communicative Language Activities } & \multirow{2}{*}{$\begin{array}{c}\begin{array}{c}\text { İletişimsel Dil } \\
\text { Faaliyetleri }\end{array} \\
\text { OBM-2009 }\end{array}$} & \multirow{2}{*}{$\begin{array}{c}\text { Bildirişimsel } \\
\text { Etkinlikler }\end{array}$} & \multirow{2}{*}{$\begin{array}{c}\begin{array}{c}\text { Dil Yeterlik } \\
\text { Sınavları }\end{array} \\
\text { Kapsamındaki } \\
\begin{array}{c}\text { Dört Beceri } \\
\text { Karşılığı }\end{array}\end{array}$} \\
\hline CEFR-2001 & CEFR-2018 & & & \\
\hline Reception & Reception & Alımlama & Algılama & Dinleme, Okuma \\
\hline Production & Production & Üretim & Üretim & Konuşma, Yazma \\
\hline Interaction & Interaction & Etkileşim & Etkileşim & Karşılıklı Konuşma \\
\hline Mediation & Mediation & Aracılık & Dil Aktarımı & - \\
\hline
\end{tabular}

CEFR, 2009 (1. bask1) ve 2013'te (2. baskı) Türkçeye çevrilmiştir. Çevirilerdeki adlandırma farklılık gösterse de içerik büyük ölçüde aynıdır.

\subsection{Dil Becerilerinin Ölçümünün Gerekliliği}

İletişimi sağlayan en önemli araç, dildir. Dil belirlenmiş kurallara göre öğrenilmeli ve öğretilmedir. Bu sebeple AOÖÇ’ye ihtiyaç duyulmuştur.

“İsviçre Hükûmetinin öncülüğünde Kasım 1991'de Rüschlikon'da düzenlenen devletlerarası sempozyumda “Avrupa'da Dil Öğreniminde Şeffaflık ve Tutarlılık: Hedefler, Değerlendirme, Belgelendirme" konusunda şu kararları almıştır:

1 Council of Europe. “Common European Framework of Reference for Languages: Learning, Teaching, Assessment. Companion Volume with New Descriptors. ” Language Policy Programme, Education Policy Division, Education Department. 2018, 30 . 
1. Üye ülkelerde daha fazla hareketlilik, kimlik ve kültürel çeşitliliğe saygı beraberinde daha etkili uluslararası iletişim, bilgiye daha kolay erişim, daha yoğun kişisel etkileşim, gelişmiş iş ilişkileri ve daha derin ortak anlayış amaçları doğrultusunda dil öğrenme ve öğretiminin yoğunlaştırılması önemlidir.

2. Bu amaçlara ulaşmak için dil öğreniminin, okul öncesi dönemden yetişkinliğe kadar eğitim sistemiyle sağlanması ve geliştirilmesi gereken, yaşam boyu sürecek bir etkinliktir.

3. Her düzeyde dil öğrenimine yol gösterecek diller için Avrupa Ortak Başvuru Metni aşağıdaki amaçlarla geliştirilmek istenmektedir:

a) Farklı ülkelerdeki eğitim kurumları arasında işbirliğini arttırmak,

b) Dil yeteneklerinde ortak bir temel oluşturmak,

c) Öğrenen, öğretmen, program geliştiriciler, sınav kurulları ve eğitim müdürlüklerine bu kurumları oluşturmakta ve çabalarını koordine etmekte yardımcı olmak". ${ }^{2}$

Yukarıda belirtilen maddeler incelendiğinde dil öğretiminde standart bir yapı oluşturulmasının, dilin öğrenilmesi açısından önemi vurgulanmıştır. Oluşturulan bu yapıyla dil öğretiminde birlik sağlanarak seviyelere göre öğretim yapılmasına olanak sağlanmıştır. Her seviye için belirlenen ölçütler, bütün diller için ortak ölçüt alındığında standart öğretim modelleri oluşacaktır. Yapılan dil ögretimlerinin dil becerilerine ve seviyelerine göre yapılması gerekmektedir. Bu becerilerin ne kadar öğrenildiği, uluslararası standartlara uygun dil yeterlik sınavlarıyla ölçülmelidir.

\subsection{Dil Becerilerinin Ölçümünde Belirlenen Ölçütler}

Öneriler Çerçevesinde belirtilen seviye tanımlayıcılarına göre o seviyeyi ölçecek sınavların oluşturulması gerekmektedir. Bu sınavlar belli özellikler taşımalıdır. Sınavlar hazırlanırken aşağıdaki üç noktaya dikkat edilmelidir:

“1. Test ve sınav içeriklerinin tam olarak belirlenmesi (neyin ölçüldüğü);

2. Bir hedefe ulaşılıp ulaşılmadığına (başarının nasıl yorumlandığı) karar vermeye yardımcı ölçütlerin saptanması;

3. Çeşitli dil yeterlik sistemlerini karşılaştırmayı sağlayan mevcut test ve sınavların yeterlik seviyelerinin tanımlanması (karşılaştırmaların nasıl yapılabildiği).

Bu noktalar, çeşitli ölçme türleriyle farklı şekillerde ilişkilidir. Birçok farklı ölçme türü ve geleneği vardır; ama belirli bir yaklaşımın (merkezî bir sınav gibi) gerektiğinde kendi didaktik değeri içerisinde bir başka yaklaşıma (öğretmenin ölçmesi gibi) üstün olmasını düşünmek yanlıştır. Ortak standartlar sisteminin en büyük değeri -Öneriler Çerçevesi’nin ortak öneri düzeylerinde olduğu gibi- onların farklı ölçme ve değerlendirme şekillerini ilişkilendirmeyi sağlayabilmesidir". ${ }^{3}$

Dil yeterlik sınavları; sınavın hazırlanması, sınavın uygulanması, sınavın değerlendirmesi aşamalarından oluşmaktadır. Sınavın uygulanmasına ilişkin bilgiler sınav yönergelerinde bildirilmektedir. Sınav hazırlanırken dikkat edilmesi gereken noktalar bulunmaktadır. Dil

2 MEB. Diller İçin Avrupa Ortak Başvuru Metni Öğrenme-Öğretme-Değerlendirme. Ankara: Talim Terbiye Kurulu Başkanlığı Yayınları, 2009, 4.

3 Telc. Diller İçin Avrupa Ortak Öneriler Çerçevesi -Öğrenim, Öğretim ve Değerlendirme [Common European Framework of Reference for Languages - Learning, Teaching and Assessment]. Frankfurt, Germany: Telc GmbH, 2013, 173 . 
yeterlik sınavları uzman bir kadro tarafından hazırlanmalıdır. Sorulardaki metinlerin seçimi, soru sayıları, soru çeşitleri, sınav süresi, değerlendirme ölçütleri dikkatli bir şekilde belirlenmelidir. Dil yeterlik sınavları büyük çapta yapılan sınavlar oldukları için hata yapılmaması gerekir. Soruları hazırlamak için en önemli araç, metinlerdir. Okuma ve dinleme becerisi, metinler üzerinden ölçülmektedir. Bu nedenle metin seçiminde dikkatli olunmalıdır.

“Milanovic'e (2002) göre metin seçimi konusunda testi hazırlayan ve uygulayan kişiler şunları yapmalıdır:

1. Metinler durumsal içerikli ve gerçek hayatı yansıtıcı olmalıdır ve tam olarak herhangi bir yerden kopyalanmamalıdır.

2. Durumlar ve konular testi alan kişinin düzeyine uygun olmalı ve yabancılık çekmeyecekleri şekilde konuların düzenlenmesi gerekmektedir.

3. Belirli bir konuyu sunarken, açık bir amaç güdülmesi ve diğer katılımcılarla beraber söz konusu duruma uygun yapılar elde edilmelidir.

4. Başarı ölçütlerinin bir konuyu tamamlarken açık olması gerekmektedir". ${ }^{4}$

Okuma ve dinleme becerisine ait metinler yukarıda belirtilen ölçütlere göre hazırlandıktan sonra metinlere bağlı soruların oluşturulması gerekmektedir.

"Soruların hazırlanması konusunda da dikkat edilmesi gereken durumlar aşağıda maddelenmiştir:

1. Gereken soru sayısı üretilmiş mi?

2. Sorular parçanın tümüne dağıtılmış mı?

3. Farklı dil yapılarına değinilmiş mi?

4. Birbirine bağlı soruların olmadığı kesin mi?

5. Teknik hatalardan kaçınılmış mı?

6. Örnek cevap verilmesi gerekiyor mu?

7. Detaylı bir cevap anahtarı ayrı bir kâğıtta hazırlandı mı?".5

Belirtilen 7 madde soru hazırlayıcılar için önemlidir. Bu maddelerde yapılacak bir hata sinavın kalitesini etkileyecektir.

\section{Yöntem/Methods}

\subsection{Araştırma Modeli}

Araştırmada, nitel araştırma yöntemlerinden durum çalışması kullanılmıştır. "Nitel durum çalışmasının en önemli özelliği bir ya da birkaç durumun derinliğine araştırılmasıdır. Yani bir duruma ilişkin etkenler (ortam, bireyler, olaylar, süreçler, vb.) bütüncül bir yaklaşımla araştırılır ve ilgili durumu nasıl etkiledikleri ve ilgili durumdan nasıl etkilendikleri üzerine odaklanır”. ${ }^{6}$

\subsection{Veri Kaynağı / Çalışma Materyali}

4 Dursun Köse. "Türkçenin Yabancı Dil Olarak Öğretiminde Sınavların Hazırlanması ve Uygulanması.”, Ankara Üniversitesi Dil Dergisi 139 (2008), 38.

5 Dursun Köse. “Türkçenin Yabancı Dil Olarak Öğretiminde Sınavların Hazırlanması ve Uygulanması.”, Ankara Üniversitesi Dil Dergisi 139 (2008), 40.

6 Ali Yıldırım, Hasan Şimşek. Sosyal Bilimlerde Nitel Araştırma Yöntemleri. (11. Baskı), Ankara: Seçkin Yayıncılık, 2018,73 . 
Araştırmanın veri kaynağı TYS ile uluslararası geçerliğe sahip dil yeterlik sınavlarıdır. Bu sınavlar TYS $^{7}$ ve ÖSYM ${ }^{8}$ tarafından eşdeğerlikleri kabul edilen dil yeterlik sınavları (İngilizce için $\mathrm{CPE}^{9}$ ve $\mathrm{CAE}^{10}$, TOEFL iBT ${ }^{11}$, PTE Akademik ${ }^{12}$; Almanca için TestDaF ${ }^{13}$, DSD $\mathrm{II}^{14}$, telc Deutsch ${ }^{15}$ ve Goethe-Zertifikat ${ }^{16}$; Fransızca için DELF \& DALF ${ }^{17}$, İspanyolca için DELE $^{18}$, İtalyanca için CELI ${ }^{19}$, Rusça için TORFL ${ }^{20}$ ' dır. Örnek sınavlar ve sınav belgeleri sınav sağlayıcıların sitelerinden indirilmiştir. Sınav sağlayıcılarla iletişime geçilerek sınavlar hakkında gerekli bilgiler toplanmış, incelenen içerik Türkçeye çevrilmiştir.

\subsection{Veri Analizi}

Verilerin analizinde içerik analizi yönteminden yararlanılmıştır. "İçerik analizinde temelde yapılan işlem, birbirine benzeyen verileri belirli kavramlar ve temalar çerçevesinde bir araya getirmek ve bunları okuyucunun anlayabileceği bir biçimde düzenleyerek yorumlamaktır". ${ }^{21}$

\section{Bulgular/Results}

Bu bölümde sınavların hangi becerilere göre hazırlandığına, sınavların soru çeşitlerine değinilecektir.

\subsection{Sınavların Hangi Becerilere Göre Hazırlandığına İlişkin Bulgular}

Sınavların içeriğinde sunulan dil becerileri ve bu becerilerin orijinal adlandırması aşağıda tablo olarak sunulmuştur

7 “Türkçe Yeterlik Sınavı”, Erişim Tarihi 8 Ocak, 2018, https://tys.yee.org.tr/.

8 "Yabancı Dil Sınavları Eşdeğerlikleri", Erişim Tarihi Şubat 25, 2016, https://www.osym.gov.tr/TR,10220/ yabanci-dil-sinavlari-esdegerlikyonergesi- ve-esdegerlik-tablosu-26022016.html.

9 “Cambridge Proficiency English", Retrieved November 5, 2018, https://www.cambridgeenglish.org/examsand-tests/proficiency/

10 "Cambridge Advanced English", Retrieved November 5, 2018, https://www.cambridgeenglish.org/exams-andtests/advanced/.

11 "Test of English as a Foreign Language İnternet Based Test", Retrieved January 25, 2018, https://www.ets.org/.

12 "Pearson Test of English Academic", Retrieved July 26, 2018, https://tr.pearson.com/tr.html.

13 "Der Test Deutsch als Fremdsprache", Retrieved January 26, 2019, https://www.testdaf.de/.

14 "Deutsches Sprachdiplom II", Retrieved July 26, 2018, https://www.bva.bund.de/SharedDocs/Organisationseinheiten/ DE/Abteilung_ZfA/Abteilung_ZfA.html.

15 "The European Language Certificates", Erişim Tarihi 26 Temmuz, 2018, https://www.telc.net/tr/sinav-katilimcilari/ dil-sinavlari.html.

16 “Goethe-Zertifikat." Retrieved January 25, 2018, https://www.goethe.de/de/index.html.

17 "Diplôme D'études En Langue Française / Diplôme Approfondi En Langue Française", Retrieved January 25, 2018, http://www.ciep.fr/en.

18 "Diplomas de Espanol Como Lengua Extranjera", Retrieved January 23, 2018, https://examenes.cervantes.es/ es/dele/examenes.

19 "Certificato Di Lingua Italiana." Retrieved January 25, 2018, https://www.cvcl.it/categorie/categoria-64?explicit=SI.

20 "Test of Russian as a Foreign Language", Retrieved January 25, 2018, http://www.pushkin.institute/Certificates/ CGT/ekzameny-v-sisteme-trki.php.

21 Ali Yıldırım, Hasan Şimşek. Sosyal Bilimlerde Nitel Araştırma Yöntemleri. (11. Baski), Ankara: Seçkin Yayıncılık, $2018,242$. 


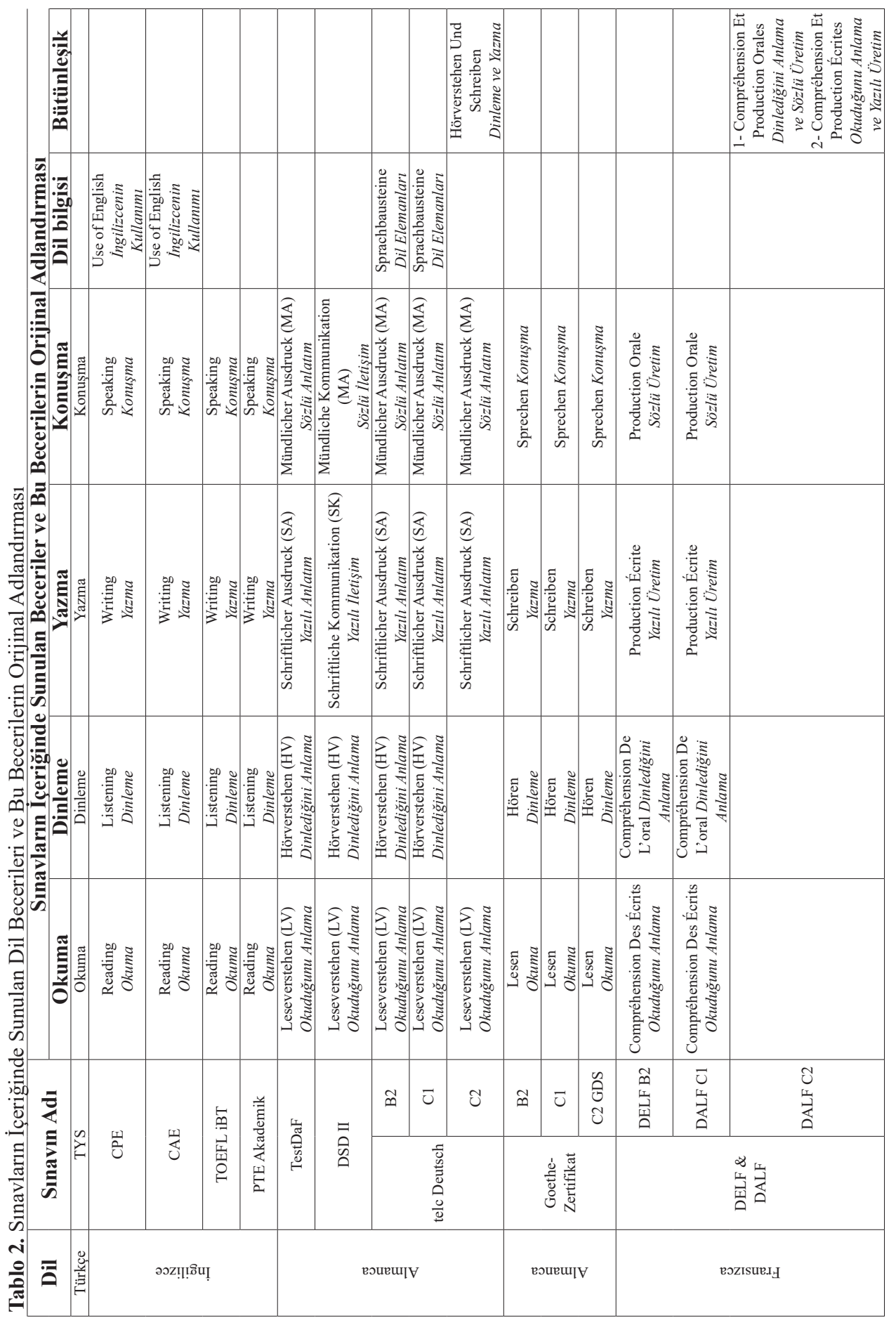




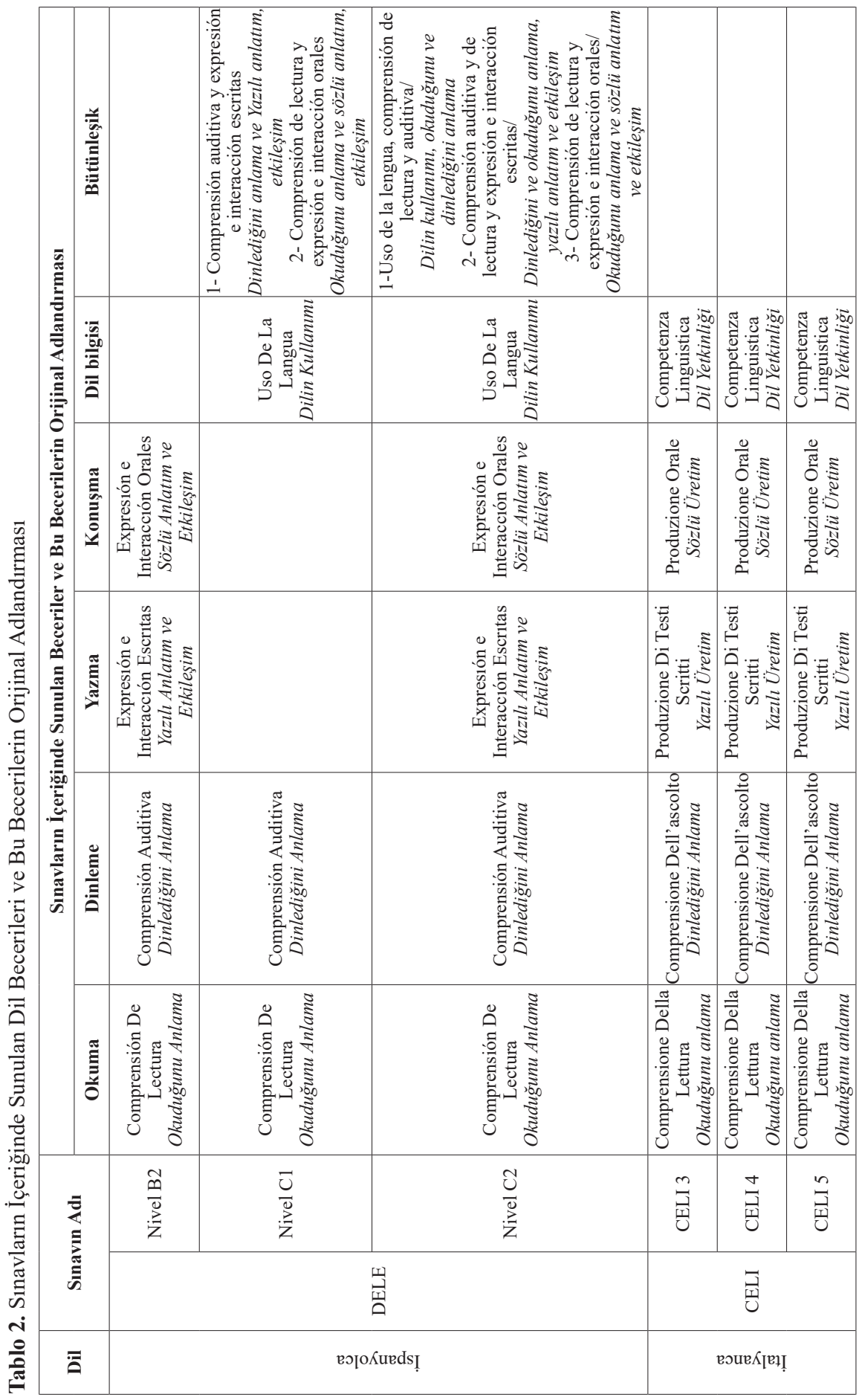


Tablo 2. Sınavların İçeriğinde Sunulan Dil Becerileri ve Bu Becerilerin Orijinal Adlandırması

\begin{tabular}{|c|c|c|c|c|c|c|c|}
\hline \multirow{3}{*}{ Rusça } & \multirow{3}{*}{ TORFL } & $\begin{array}{c}\text { Level } \\
2\end{array}$ & $\begin{array}{c}\text { Чтение } \\
\text { (Chteniye) } \\
\text { Okuma }\end{array}$ & $\begin{array}{c}\text { Аудирование } \\
\text { (Audirovanie) } \\
\text { Dinleme }\end{array}$ & $\begin{array}{c}\text { Письмо } \\
\text { (Pis'mo) } \\
\text { Yazma }\end{array}$ & $\begin{array}{c}\text { Говорение } \\
\text { (Govorenie) } \\
\text { Коnuşma }\end{array}$ & $\begin{array}{c}\text { Грамматика. } \\
\text { Лексика } \\
\text { (Grammatika. } \\
\text { Leksika) } \\
\text { Dil bilgisi, } \\
\text { sözcük bilgisi }\end{array}$ \\
\hline & & $\begin{array}{c}\text { Level } \\
3\end{array}$ & $\begin{array}{c}\text { Чтение } \\
\text { (Chteniye) } \\
\text { Okuma }\end{array}$ & $\begin{array}{c}\text { Аудирование } \\
\text { (Audirovanie) } \\
\text { Dinleme }\end{array}$ & $\begin{array}{c}\text { Письмо } \\
\text { (Pis'mo) } \\
\text { Yazma }\end{array}$ & $\begin{array}{c}\text { Говорение } \\
\text { (Govorenie) } \\
\text { Копиşma }\end{array}$ & $\begin{array}{c}\text { Грамматика. } \\
\text { Лексика } \\
\text { (Grammatika. } \\
\text { Leksika) } \\
\text { Dil bilgisi, } \\
\text { sözcük bilgisi }\end{array}$ \\
\hline & & $\begin{array}{c}\text { Level } \\
4\end{array}$ & $\begin{array}{c}\text { Чтение } \\
\text { (Chteniye) } \\
\text { Okuma }\end{array}$ & $\begin{array}{c}\text { Аудирование } \\
\text { (Audirovanie) } \\
\text { Dinleme }\end{array}$ & $\begin{array}{c}\text { Письмо } \\
\text { (Pis'mo) } \\
\text { Yazma }\end{array}$ & $\begin{array}{c}\text { Говорение } \\
\text { (Govorenie) } \\
\text { Копиşma }\end{array}$ & $\begin{array}{c}\text { Грамматика. } \\
\text { Лексика } \\
\text { (Grammatika. } \\
\text { Leksika) } \\
\text { Dil bilgisi, } \\
\text { sözcük bilgisi }\end{array}$ \\
\hline
\end{tabular}

Sınavların tamamı dört dil becerisine göre hazırlanmıştır. Tablolar incelendiğinde okuma sınavları, "Okuma”, "Okuduğunu Anlama” olarak adlandırılmıştır. Dinleme sınavları, "Dinleme”, "Dinlediğini Anlama” olarak adlandırılmıştır. Yazma sınavları, "Yazma", "Yazılı İletişim", "Yazılı Üretim”, "Yazılı Anlatım”, "Yazılı Anlatım ve Etkileşim” olarak adlandırılmıştır. Konuşma sınavları, “Konuşma”, “Sözlü Anlatım”, “Sözlü İletişim”, “Sözlü Üretim”, “Sözlü Anlatım ve Etkileşim” olarak adlandırılmıştır.

Dil bilgisi bir beceri olmamakla beraber dil becerilerini geliştirmesi açısından önemlidir. Bu sebeple incelenen sınavların bir bölümünde "İngilizcenin Kullanımı", "Dil Elemanları", "Dil Yetkinliği”, "Dilin Kullanımı” adıyla gerek okuma bölümünün içinde gerekse ayrı bir bölüm olarak dil bilgisi soruları bulunmaktadır. Dil bilgisi soruları CELI ve TORFL sınavlarının tamamında ayrı bir bölümde bulunmaktadır.

Bütünleşik beceri soruları telc Deutsch C2'de "Dinleme ve Yazma”, DALF C2'de “Dinlediğini Anlama ve Sözlü Üretim”, “Okuduğunu Anlama ve Yazılı Üretim”, DELE Nivel C1'de "Dinlediğini Anlama ve Yazılı Anlatım, Etkileşim”, “Okuduğunu Anlama ve Sözlü Anlatım, Etkileşim”, DELE Nivel C2'de “Dilin Kullanımı, Okuduğunu ve Dinlediğini Anlama", "Dinlediğini ve Okuduğunu Anlama, Yazılı Anlatım ve Etkileşim”, “Okuduğunu Anlama ve Sözlü Anlatım ve Etkileşim” olarak hazırlanmıştır.

\subsection{Sınavların Soru Çeşitlerine İlişkin Bulgular}

İncelenen sınavlardaki okuma becerisine ait soru çeşitleri aşağıda tablolaştırılmıştır: 
Tablo 3. Sınavlarda Sunulan Okuma Becerisi Soru Çeşitlerine İlişkin Bilgiler

\begin{tabular}{|c|c|c|c|c|c|c|c|c|c|c|c|c|c|}
\hline \multirow[b]{2}{*}{ Dil } & \multirow{2}{*}{\multicolumn{2}{|c|}{ Sınavın Adı }} & \multicolumn{11}{|c|}{ Okuma Becerisine Ait Soru Çeşitleri } \\
\hline & & & 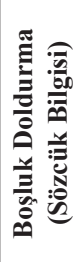 & ڤొ & 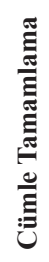 & 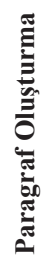 & 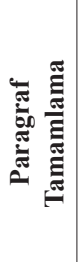 & 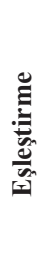 & 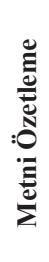 & 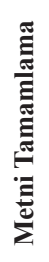 & 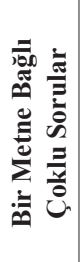 & 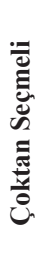 & 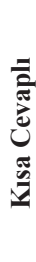 \\
\hline Türkçe & TYS & & $\checkmark$ & $\checkmark$ & & & & & & & $\checkmark$ & $\checkmark$ & \\
\hline \multirow{4}{*}{ İngilizce } & CPE & & $\checkmark$ & & $\checkmark$ & & & & & $\checkmark$ & $\checkmark$ & $\checkmark$ & $\sqrt{ }$ \\
\hline & CAE & & $\checkmark$ & & $\checkmark$ & & & & & $\checkmark$ & $\checkmark$ & $\checkmark$ & $\checkmark$ \\
\hline & TOEFL iBT & & & & & & & & $\checkmark$ & & $\checkmark$ & $\checkmark$ & \\
\hline & PTE Akadem & & $\checkmark$ & & $\checkmark$ & $\checkmark$ & & & & & & $\checkmark$ & \\
\hline \multirow{8}{*}{ Almanca } & TestDaF & & & $\checkmark$ & & & & $\checkmark$ & & & & $\checkmark$ & \\
\hline & DSD II & & & & & & $\checkmark$ & & & & $\checkmark$ & $\checkmark$ & \\
\hline & \multirow{3}{*}{ telc Deutsch } & B2 & & & & & & $\checkmark$ & & & $\checkmark$ & $\checkmark$ & \\
\hline & & $\mathrm{C} 1$ & & $\checkmark$ & & & & $\checkmark$ & & $\checkmark$ & & $\checkmark$ & \\
\hline & & $\mathrm{C} 2$ & & & & $\checkmark$ & & & & & $\checkmark$ & $\checkmark$ & \\
\hline & \multirow{3}{*}{$\begin{array}{l}\text { Goethe- } \\
\text { Zertifikat }\end{array}$} & B2 & & $\checkmark$ & & & & $\checkmark$ & & & & $\checkmark$ & \\
\hline & & C1 & & & & & & $\checkmark$ & & $\checkmark$ & $\checkmark$ & $\checkmark$ & \\
\hline & & C2 GDS & & & & & $\checkmark$ & & & $\checkmark$ & & $\checkmark$ & \\
\hline \multirow{3}{*}{ Fransizca } & \multirow{3}{*}{$\begin{array}{l}\text { DELF \& } \\
\text { DALF }\end{array}$} & DELF B2 & & $\checkmark$ & & & & & & & $\checkmark$ & $\checkmark$ & $\checkmark$ \\
\hline & & DALF C1 & & $\checkmark$ & & & & & & & $\checkmark$ & $\checkmark$ & $\checkmark$ \\
\hline & & DALF C2 & & & & & & & & & & & $\checkmark$ \\
\hline \multirow{3}{*}{ İspanyolca } & \multirow{3}{*}{ DELE } & Nivel B2 & & & $\checkmark$ & & $\checkmark$ & & & & $\checkmark$ & $\checkmark$ & \\
\hline & & Nivel C1 & & & $\checkmark$ & & $\checkmark$ & & & & $\checkmark$ & $\sqrt{ }$ & \\
\hline & & Nivel C2 & & & & & $\checkmark$ & & & & $\checkmark$ & $\checkmark$ & \\
\hline \multirow{3}{*}{ İtalyanca } & \multirow{3}{*}{ CELI } & CELI 3 & & & & & & $\checkmark$ & & & $\checkmark$ & $\checkmark$ & $\checkmark$ \\
\hline & & CELI 4 & & & & & & $\checkmark$ & & & $\checkmark$ & $\checkmark$ & $\checkmark$ \\
\hline & & CELI 5 & & & & & & $\checkmark$ & & & $\checkmark$ & $\checkmark$ & $\checkmark$ \\
\hline \multirow{3}{*}{ Rusça } & \multirow{3}{*}{ TORFL } & Level 2 & & & & & & & & & $\checkmark$ & $\checkmark$ & \\
\hline & & Level 3 & & & & $\checkmark$ & & $\checkmark$ & & & $\checkmark$ & $\checkmark$ & $\checkmark$ \\
\hline & & Level 4 & & & & $\checkmark$ & & & & & $\checkmark$ & $\checkmark$ & $\checkmark$ \\
\hline
\end{tabular}

Okuma bölümündeki soru çeşitleri incelendiğinde TYS'de boşluk doldurma (sözcük bilgisi), doğru-yanlış, grafik okuma, çoktan seçmeli, bir metne bağlı çoklu soru çeşitleri bulunmaktadır. Bu soru çeşitlerinden boşluk doldurma (sözcük bilgisi), doğru-yanlış, çoktan seçmeli, bir metne bağlı çoklu sorular diğer dil yeterlik sınavlarında da yer almaktadır. Grafik okuma soru çeşidi diğer dil yeterlik sınavlarında -DELE Nivel C2 bütünleşik soru çeşidi hariç- bulunmamaktadır. Bu yönüyle TYS'de farklı bir soru çeşidi bulunmaktadır. Diğer dil yeterlik sınavlarında bulunup TYS' de bulunmayan soru çeşitleri cümle tamamlama, paragraf 
oluşturma, paragraf tamamlama, eşleştirme, metni özetleme, metni tamamlama, kısa cevaplı sorular ve bütünleşik beceri sorularıdır.

Bazı dil yeterlik sınavlarının okuma becerisi sınavlarında örnek çözüm uygulaması bulunmaktadır. Okuma becerisine ait sorular incelendiğinde CPE, CAE, TestDaF, DSD II, telc Deutsch C1, telc Deutsch C2, Goethe-Zertifikat B2, Goethe-Zertifikat C1, GoetheZertifikat C2 GDS, DELE Nivel C1, DELE Nivel C2, CELI 4, CELI 5 sinavlarında örnek çözüm bulunmaktadır.

İncelenen sınavlardaki dinleme becerisine ait soru çeşitleri aşağıda tablolaştırılmıştır:

Tablo 4. Sınavlarda Sunulan Dinleme Becerisi Soru Çeşitlerine İlişkin Bilgiler

\begin{tabular}{|c|c|c|c|c|c|c|c|c|c|c|}
\hline \multirow[b]{2}{*}{ Dil } & \multirow{2}{*}{\multicolumn{2}{|c|}{ Sınavın Adı }} & \multicolumn{8}{|c|}{ Dinleme Becerisine Ait Soru Çeşitleri } \\
\hline & & & 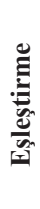 & 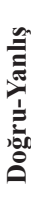 & 总 & 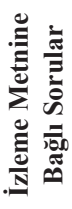 & 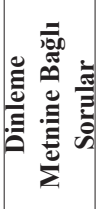 & 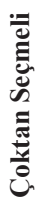 & 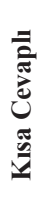 & 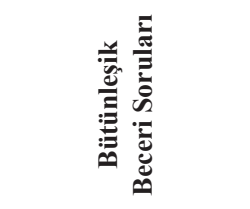 \\
\hline Türkçe & TYS & & $\checkmark$ & $\checkmark$ & $\checkmark$ & & $\checkmark$ & $\checkmark$ & & \\
\hline \multirow{4}{*}{ İngilizce } & $\mathrm{CPE}$ & & $\checkmark$ & & $\checkmark$ & & $\checkmark$ & $\checkmark$ & $\checkmark$ & \\
\hline & CAE & & $\checkmark$ & & $\checkmark$ & & $\checkmark$ & $\checkmark$ & $\checkmark$ & \\
\hline & TOEFL iBT & & & & & & $\checkmark$ & $\checkmark$ & & \\
\hline & PTE Akaden & & & $\checkmark$ & $\checkmark$ & & $\checkmark$ & $\checkmark$ & $\checkmark$ & Dinleme ve Yazma \\
\hline \multirow{8}{*}{ Almanca } & TestDaF & & & $\checkmark$ & $\checkmark$ & & $\checkmark$ & & $\checkmark$ & Dinleme ve Yazma \\
\hline & DSD II & & $\checkmark$ & & & & $\checkmark$ & $\checkmark$ & & \\
\hline & & B2 & & $\checkmark$ & & & & & & \\
\hline & telc Deutsch & $\mathrm{C} 1$ & $\checkmark$ & $\checkmark$ & & & $\checkmark$ & $\checkmark$ & $\checkmark$ & Dinleme ve Yazma \\
\hline & & $\mathrm{C} 2$ & & & & & & & $\checkmark$ & Dinleme ve Yazma \\
\hline & Goethe- & B2 & & & $\checkmark$ & & $\checkmark$ & $\checkmark$ & $\checkmark$ & Dinleme ve Yazma \\
\hline & Zertifikat & C1 & & & & & $\checkmark$ & $\checkmark$ & & \\
\hline & & C2 GDS & & $\checkmark$ & & & $\checkmark$ & $\checkmark$ & & \\
\hline \multirow{3}{*}{ Fransizca } & \multirow{3}{*}{$\begin{array}{l}\text { DELF \& } \\
\text { DALF }\end{array}$} & DELF B2 & & & & & $\checkmark$ & $\checkmark$ & $\checkmark$ & Dinleme ve Yazma \\
\hline & & DALF C1 & & & & & $\checkmark$ & $\checkmark$ & $\checkmark$ & Dinleme ve Yazma \\
\hline & & DALF C2 & & & & & & & & Dinleme ve Konuşma \\
\hline \multirow{3}{*}{ İspanyolca } & \multirow{3}{*}{ DELE } & Nivel B2 & $\checkmark$ & & & & $\checkmark$ & $\checkmark$ & & \\
\hline & & Nivel C1 & & & $\checkmark$ & & $\checkmark$ & $\checkmark$ & & \\
\hline & & Nivel C2 & & & & & & & & Dinleme ve Yazma \\
\hline \multirow{3}{*}{ İtalyanca } & \multirow{3}{*}{ CELI } & CELI 3 & & & $\checkmark$ & & $\checkmark$ & $\checkmark$ & $\checkmark$ & Dinleme ve Yazma \\
\hline & & CELI 4 & & $\checkmark$ & $\checkmark$ & & $\checkmark$ & $\checkmark$ & $\checkmark$ & Dinleme ve Yazma \\
\hline & & CELI 5 & & $\checkmark$ & $\checkmark$ & & $\checkmark$ & $\checkmark$ & $\checkmark$ & Dinleme ve Yazma \\
\hline \multirow{3}{*}{ Rusça } & \multirow{3}{*}{ TORFL } & Level 2 & & & & $\checkmark$ & $\checkmark$ & $\checkmark$ & & \\
\hline & & Level 3 & & & & $\checkmark$ & $\checkmark$ & $\checkmark$ & & \\
\hline & & Level 4 & & & & $\checkmark$ & $\checkmark$ & $\checkmark$ & & \\
\hline
\end{tabular}


Dinleme bölümündeki soru çeşitleri incelendiğinde TYS' de eşleştirme, doğru-yanlış, cümle tamamlama, çoktan seçmeli sorular bulunmaktadır. TYS'de olup diğer dil yeterlik sınavlarında olmayan bir soru çeşidi bulunmamaktadır. Diğer dil yeterlik sınavlarında olup TYS' de olmayan soru çeşitleri ise izleme metnine bağlı sorular, kısa cevaplı sorular, bütünleşik beceri sorularıdır.

Okuma sınavında örnek çözüm uygulaması bulunduğu hâlde dinleme bölümünde örnek çözüm DELE Nivel B2, Goethe-Zertifikat B2 sınavlarında 1 görevde bulunmaktadır. Dinleme sınavında örnek çözüm uygulaması yaygın değildir.

Dil yeterlik sınavlarının bazı görevlerinde dinleme metni 2. kez dinletilmektedir. TestDaF' ta 1 görev, DSD II'de 1 görev, Goethe-Zertifikat B2'de 1 görev, Goethe-Zertifikat C1'de 1 görev, Goethe-Zertifikat C2 GDS' de 1 görev, DELF B2'de 1 görev, DALF C1'de 1 görev, DELE Nivel B2'de 5 görev, DELE Nivel C1'de 5 görev, DELE Nivel C2'de 4 görev, CELI 3'de 2 görev, CELI 4'de 2 görev, CELI 5'de 2 görev metinlerin ikinci kez dinletildiği sinavlar ve görev sayılarıdır.

Örnek sınavlarda dinleme sınavının ses dosyasıyla beraber yazılı metin dosyası da bulunmaktadır. Dinletilen ses dosyasının yazılı hâli örnek sınav dosyalarında fonetik yazı (transkripsiyon) adıyla bulunmaktadır. Özellikle dinleme metinlerinin takip edilmesi açısından kolaylık sağlayan fonetik yazı (transkripsiyon) dosyası, aday için sınav öncesinde sınava çalışmasını kolaylaştırabilir. Dinleme metniyle beraber fonetik yazı (transkripsiyon) dosyasını paylaşan sınavlar TestDaF, DSD II, telc Deutsch B2, telc Deutsch C1, telc Deutsch C2, GoetheZertifikat B2, Goethe-Zertifikat C1, Goethe-Zertifikat C2 GDS, DELF B2, DALF C1, DALF C2, DELE Nivel B2, DELE Nivel C1, DELE Nivel C2, TORFL Level 2, TORFL Level 3, TORFL Level 4 sinavlarıdır. TYS, CAE, CPE, PTE Akademik, TOEFL iBT, CELI 3, CELI 4, CELI 5 örnek sınavlarında paylaşılan fonetik yazıya rastlanılmamıştır. TYS, salt olarak sınavı örneklemeyi amaçladığı için fonetik yazıyı (transkripsiyonu) paylaşmamaktadır.

İncelenen sınavlardaki yazma becerisine ait soru çeşitleri aşağıda tablolaştırılmıştır: 
Tablo 5. Sınavlarda Sunulan Yazma Becerisi Soru Çeşitlerine İlişkin Bilgiler

\begin{tabular}{|c|c|c|c|c|c|c|c|c|}
\hline \multirow[b]{2}{*}{ Dil } & \multirow{2}{*}{\multicolumn{2}{|c|}{ Sinavın Adı }} & \multicolumn{6}{|c|}{ Yazma Becerisine Ait Soru Çeşitleri } \\
\hline & & & 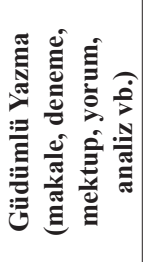 & 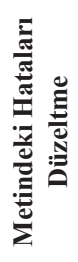 & 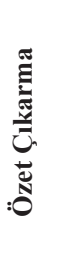 & 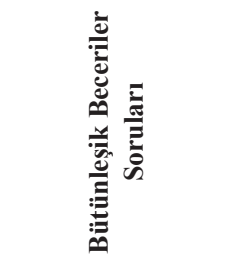 & 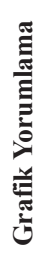 & 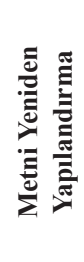 \\
\hline Türkçe & TYS & & $\checkmark$ & & & & & \\
\hline \multirow{4}{*}{ İngilizce } & \multicolumn{2}{|l|}{ CPE } & $\checkmark$ & & & & & \\
\hline & \multicolumn{2}{|l|}{ CAE } & $\checkmark$ & & & & & \\
\hline & \multicolumn{2}{|l|}{ TOEFL iBT } & $\checkmark$ & & & Dinlediğini Yazma & & \\
\hline & \multicolumn{2}{|c|}{ PTE Akademik } & $\checkmark$ & & $\checkmark$ & & & \\
\hline \multirow{8}{*}{ Almanca } & \multicolumn{2}{|c|}{ TestDaF } & $\checkmark$ & & & & $\checkmark$ & \\
\hline & \multicolumn{2}{|l|}{ DSD II } & $\checkmark$ & & & & & \\
\hline & \multirow{3}{*}{ telc Deutsch } & B2 & $\checkmark$ & & & & & \\
\hline & & $\mathrm{C} 1$ & $\checkmark$ & & & & & \\
\hline & & $\mathrm{C} 2$ & $\checkmark$ & & & & & \\
\hline & \multirow{3}{*}{$\begin{array}{l}\text { Goethe- } \\
\text { Zertifikat }\end{array}$} & B2 & $\checkmark$ & $\checkmark$ & & & & \\
\hline & & $\mathrm{C} 1$ & $\checkmark$ & $\checkmark$ & & & & \\
\hline & & C2 GDS & $\checkmark$ & $\checkmark$ & & & & \\
\hline \multirow{3}{*}{ Fransizca } & \multirow{3}{*}{$\begin{array}{l}\text { DELF \& } \\
\text { DALF }\end{array}$} & DELF B2 & $\checkmark$ & & & & & \\
\hline & & DALF C1 & $\checkmark$ & & & & & \\
\hline & & DALF C2 & & & & Okuduğunu Yazma & & \\
\hline \multirow{3}{*}{ İspanyolca } & \multirow{3}{*}{ DELE } & Nivel B2 & $\checkmark$ & & & Dinlediğini yazma & & \\
\hline & & Nivel C1 & $\checkmark$ & & & Dinlediğini Yazma & & \\
\hline & & Nivel C2 & & & & $\begin{array}{c}\text { Dinlediğini ve } \\
\text { Okuduğunu Yazma }\end{array}$ & $\checkmark$ & $\checkmark$ \\
\hline \multirow{3}{*}{ İtalyanca } & \multirow{3}{*}{ CELI } & CELI 3 & $\checkmark$ & & & & & \\
\hline & & CELI 4 & $\checkmark$ & & $\checkmark$ & & & \\
\hline & & CELI 5 & $\checkmark$ & & & & & \\
\hline \multirow{3}{*}{ Rusça } & \multirow{3}{*}{ TORFL } & Level 2 & $\checkmark$ & & & & & \\
\hline & & Level 3 & & & $\checkmark$ & & & \\
\hline & & Level 4 & $\checkmark$ & & & Dinlediğini Yazma & & $\checkmark$ \\
\hline
\end{tabular}

Yazma bölümündeki TYS soru çeşitleri incelendiğinde güdümlü yazma konuları bulunmaktadır. Bu konular diğer dil yeterlik sınavlarında ortak kullanılan soru çeşitlerindedir. TYS'de olup diğer dil yeterlik sınavlarında olmayan soru çeşidi bulunmamaktadır. Diğer dil yeterlik sınavlarında olup TYS'de olmayan soru çeşitleri metindeki hataları düzeltme, özet çıkarma, bütünleşik beceri soruları, grafik yorumlama, metni yeniden yapılandırmadır.

Yazma sınavlarındaki görev ve sözcük sayısı farklılık göstermektedir. Bu bilgi aşağıda tablolaştırılmıştır: 
Tablo 6. Yazma Sınavlarındaki Görev Sayısına ve Yazılması İstenen Sözcük Sayısına İlişkin Bilgiler

\begin{tabular}{|c|c|c|c|c|}
\hline \multirow[t]{2}{*}{ Dil } & \multirow{2}{*}{\multicolumn{2}{|c|}{ Sinavin Adı }} & \multicolumn{2}{|c|}{$\begin{array}{c}\text { Yazma Sınavlarındaki Görev Sayısı ve Yazılması İstenen } \\
\text { Sözcük Sayısı }\end{array}$} \\
\hline & & & Görev Sayısı & Yazılması İstenen En Az Sözcük Sayısı \\
\hline Türkçe & TYS & & 2 & 325 sözcük \\
\hline \multirow{4}{*}{ İngilizce } & \multicolumn{2}{|l|}{$\mathrm{CPE}$} & 2 & 520 sözcük \\
\hline & \multicolumn{2}{|l|}{ CAE } & 2 & 440 sözcük \\
\hline & \multicolumn{2}{|l|}{ TOEFL iBT } & 2 & 450 sözcük \\
\hline & \multicolumn{2}{|l|}{ PTE Akademik } & 3 & 210 sözcük \\
\hline \multirow{8}{*}{ Almanca } & \multicolumn{2}{|l|}{ TestDaF } & 1 & Belirtilmemiş. \\
\hline & \multicolumn{2}{|l|}{ DSD II } & 1 & 200 sözcük \\
\hline & \multirow{3}{*}{ telc Deutsch } & $\mathrm{B} 2$ & 1 & 150 sözcük \\
\hline & & $\mathrm{C} 1$ & 1 & 350 sözcük \\
\hline & & $\mathrm{C} 2$ & 1 & Belirtilmemiş. \\
\hline & \multirow{3}{*}{ Goethe- Zertifikat } & B2 & 2 & 180 sözcük \\
\hline & & $\mathrm{C} 1$ & 2 & 200 sözcük \\
\hline & & C2 GDS & 2 & 350 sözcük \\
\hline \multirow{3}{*}{ Fransizca } & \multirow{3}{*}{ DELF \& DALF } & DELF B2 & 1 & 250 sözcük \\
\hline & & DALF C1 & 2 & 450 sözcük \\
\hline & & DALF C2 & 1 & 700 sözcük \\
\hline \multirow{3}{*}{ İspanyolca } & \multirow{3}{*}{ DELE } & Nivel B2 & 2 & 300 sözcük \\
\hline & & Nivel C1 & 2 & 440 sözcük \\
\hline & & Nivel C2 & 3 & 850 sözcük \\
\hline \multirow{3}{*}{ İtalyanca } & \multirow{3}{*}{ CELI } & CELI 3 & 2 & 200 sözcük \\
\hline & & CELI 4 & 2 & 370 sözcük \\
\hline & & CELI 5 & 2 & 490 sözcük \\
\hline \multirow{3}{*}{ Rusça } & \multirow{3}{*}{ TORFL } & Level 2 & 3 & 200 sözcük \\
\hline & & Level 3 & 3 & 400 sözcük \\
\hline & & Level 4 & 3 & 650 sözcük \\
\hline
\end{tabular}

13 sınavda 2 görev, 7 sinavda 1 görev, 5 sinavda 3 görev bulunmaktadır. TYS'de, çoğu dil yeterlik sınavının tercih ettiği 2 görevli yazma becerisi sorusu vardır. Tek sınavlar arasındaki yazma sınavında yazılması istenen sözcük sayısının en az olduğu sınav 200 sözcükle DSD II; en fazla olduğu sınav 520 sözcükle CPE'dir. Seviye sınavları arasındaki yazma sınavında yazılması istenen sözcük sayısının en az olduğu sınav 150 sözcükle telc Deutsch B2; en fazla olduğu 850 sözcükle DELE Nivel C2'dir. TYS, yazma sınavında 23 sınav içerisinde -alt sınır belirtilmemiş 2 sınav çıkarıldı- en yazılması istenen en az sözcük sayısı, 9 dil yeterlik sınavındaki sözcük sayısından fazla; 13 dil yeterlik sınavındaki sözcük sayısından azdır.

Yazma sınavlarında görevlerden birini seçme gibi alternatifli sorular bulunmaktadır. $\mathrm{Bu}$ sorular CPE, CAE, telc Deutsch C1, Goethe-Zertifikat B2, Goethe-Zertifikat C1, GoetheZertifikat C2 GDS, DELE Nivel B2, DELE Nivel C1, CELI 3, CELI 4, CELI 5 sinavlarında vardır. Bu sorularda bir göreve ait 2, 3 ya da 4 metinden, sorudan, grafikten, resimden birinin seçilip yazılması istenmektedir. Adayların ilgilerinin farklı olduğu düşünüldüğünde bu şekilde 
alternatif sorular aday için olumludur. "Çünkü yazma becerisi dil becerisi dışında metin türleri ve tümceler arasında bütünlük oluşturan zaman açısından bir sıralama, neden-sonuç, süreç gibi mantıksal bilgiye dayanan ilişkilerin yanı sıra akıl yürütme, anlamsal ağların canlandırılması, analiz, sentez, planlama gibi kontrol merkezi bellek olan bir dizi zihinsel strateji içerir". ${ }^{22}$ TYS'nin yazma görevlerinde böyle bir uygulama bulunmamaktadır. 2 görev için verilen birer soru bulunmaktadir.

İncelenen sınavlardaki konuşma becerisine ait soru çeşitleri aşağıda tablolaştırılmıştır:

Tablo 7. Sınavlarda Sunulan Konuşma Becerisi Soru Çeşitlerine İlişkin Bilgiler

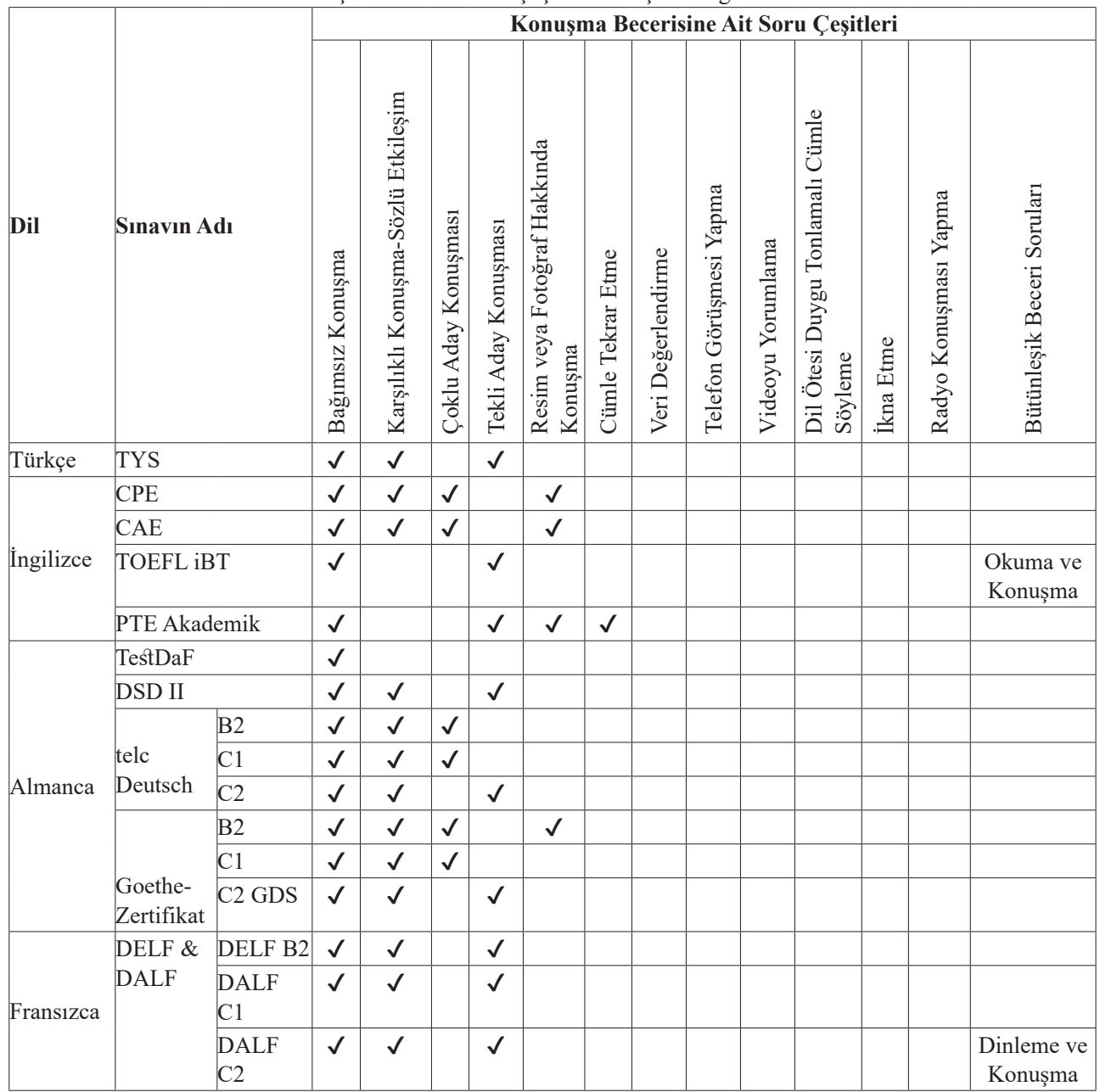

22 Sedat Maden, Ömer Dincel, Aslı Maden. "Türkçeyi Yabancı Dil Olarak Öğrenenlerin Yazma Kaygıları.” Uluslararası Türkçe Edebiyat Kültür Eğitim (TEKE) Dergisi 4(2) (2015), 749. DOI: 10.7884/teke.488 


\begin{tabular}{|c|c|c|c|c|c|c|c|c|c|c|c|c|c|}
\hline \multirow{3}{*}{ İspanyolca } & \multirow{3}{*}{ DELE } & Nivel B2 & $\checkmark$ & $\checkmark$ & $\checkmark$ & & $\checkmark$ & & & & & & \\
\hline & & Nivel C1 & $\checkmark$ & $\checkmark$ & $\checkmark$ & $\sqrt{ }$ & & & & & & & $\begin{array}{l}\text { Okuma ve } \\
\text { Konuşma }\end{array}$ \\
\hline & & Nivel C2 & $\checkmark$ & $\checkmark$ & $\checkmark$ & $\checkmark$ & & & & & & & $\begin{array}{l}\text { Okuma ve } \\
\text { Konuşma }\end{array}$ \\
\hline \multirow{3}{*}{ İtalyanca } & \multirow[b]{3}{*}{ CELI } & CELI 3 & $\checkmark$ & $\checkmark$ & $\checkmark$ & $\checkmark$ & & & & & & & \\
\hline & & CELI 4 & $\checkmark$ & $\checkmark$ & $\checkmark$ & $\checkmark$ & & & & & & & \\
\hline & & CELI 5 & $\checkmark$ & $\checkmark$ & $\checkmark$ & $\checkmark$ & & & & & & & \\
\hline \multirow{3}{*}{ Rusça } & \multirow{3}{*}{ TORFL } & Level 2 & $\checkmark$ & $\checkmark$ & $\checkmark$ & & & $\checkmark$ & $\checkmark$ & $\checkmark$ & & & \\
\hline & & Level 3 & $\checkmark$ & $\checkmark$ & $\checkmark$ & & & & $\checkmark$ & & $\checkmark$ & & \\
\hline & & Level 4 & $\checkmark$ & $\checkmark$ & $\checkmark$ & & & & & & & $\checkmark$ & \\
\hline
\end{tabular}

Konuşma sınavındaki TYS'nin soru çeşitleri ve uygulamaları incelendiğinde sınavda bağımsız ve karşılıklı konuşma olmak üzere 2 bölüm vardır. Bağımsız konuşmada adayın seçtiği karttaki konuya ya da alternatifli birden çok seçmeli konuya göre konuşma yapması istenmektedir. Karşılıklı konuşmada adayın seçtiği karttaki konuya göre muhatabın sorduğu 7 soruya cevap vermesi istenmektedir. TYS'de olup diğer sınavlarda olmayan soru türleri bulunmamaktadır. Diğer dil yeterlik sınavlarında olup TYS'de olmayan soru çeşitleri ve uygulaması resim veya fotoğraf hakkında konuşma, cümle tekrar etme, veri değerlendirme, telefon görüşmesi yapma, videoyu yorumlama, duygu tonlamalı cümle söyleme (dil ötesi), ikna etme, radyo konuşması yapma, bütünleşik beceri soruları, çoklu aday konuşmasıdır.

Konuşma sınavının uygulanması diğer beceri sınavlarından farklıdır. Aday/adaylar belirlenen sınıflarda ya 1 kişi ya 2 kişi ya da 3 kişi olarak sözlü sınava alınmaktadır. Sınava kaç adayın gireceği sınavlara göre farklılık göstermektedir. Tek sınavlardaki uygulama, seviye sınavlarındaki uygulama, internet tabanlı sınavlardaki uygulama farklıdır. Aday sayısı aynı zamanda soru çeşitlerini de etkilemektedir. Çoklu adayın girdiği sınavda görevlerden bazısı, adayların birbirlerine soru sorması, birbirleriyle tartışması, sözlü etkileşim şeklinde olmaktadır. İnternet tabanlı sınav uygulamasında ise yönergelere göre konuşma yapılması istenmektedir.

İncelenen sınavlarda dil bilgisi bölümüne ait soru içerikleri aşağıda tablolaştırılmıştır: 
Türkçe Yeterlik Sınavı́nın (TYS) Uluslararası Geçerliğe Sahip Bazı Dil Yeterlik Sınavlarıyla İçerik...

Tablo 8. Sınavlarda Sunulan Dil Bilgisi Soru Çeşitlerine İlişskin Bilgiler

\begin{tabular}{|c|c|c|c|c|c|c|c|}
\hline \multirow[b]{2}{*}{ Dil } & \multirow{2}{*}{\multicolumn{2}{|c|}{ Sınavın Adı }} & \multicolumn{5}{|c|}{ Dil Bilgisi Bölümündeki Soru Çeşitleri } \\
\hline & & & $\begin{array}{c}\text { Sözcük } \\
\text { Bilgisi }\end{array}$ & $\begin{array}{l}\text { Sözcük } \\
\text { Türleri }\end{array}$ & $\begin{array}{l}\text { Cümle } \\
\text { Kurma }\end{array}$ & $\begin{array}{c}\text { Yazım } \\
\text { Hatasını } \\
\text { Düzeltme }\end{array}$ & $\begin{array}{c}\text { Eş-Yakın } \\
\text { Anlamlı } \\
\text { Iffadeler }\end{array}$ \\
\hline Türkçe & TYS & & & & & & \\
\hline \multirow{4}{*}{ İngilizce } & \multicolumn{2}{|l|}{ CPE } & $\checkmark$ & $\checkmark$ & $\checkmark$ & & \\
\hline & \multicolumn{2}{|l|}{$\mathrm{CAE}$} & $\checkmark$ & $\checkmark$ & $\checkmark$ & & \\
\hline & \multicolumn{2}{|l|}{ TOEFL iBT } & & & & & \\
\hline & \multicolumn{2}{|c|}{ PTE Akademik } & & & & & \\
\hline \multirow{8}{*}{ Almanca } & \multicolumn{2}{|c|}{ TestDaF } & & & & & \\
\hline & \multicolumn{2}{|l|}{ DSD II } & & & & & \\
\hline & \multirow{3}{*}{ telc Deutsch } & $\mathrm{B} 2$ & $\checkmark$ & & & & \\
\hline & & $\mathrm{C} 1$ & $\checkmark$ & & & & \\
\hline & & $\mathrm{C} 2$ & & & & & \\
\hline & \multirow{3}{*}{$\begin{array}{l}\text { Goethe- } \\
\text { Zertifikat }\end{array}$} & $\mathrm{B} 2$ & & & & & \\
\hline & & $\mathrm{C} 1$ & & & & & \\
\hline & & C2 GDS & & & & & \\
\hline \multirow{3}{*}{ Fransizca } & \multirow{3}{*}{$\begin{array}{l}\text { DELF \& } \\
\text { DALF }\end{array}$} & DELF B2 & & & & & \\
\hline & & DALF C1 & & & & & \\
\hline & & DALF C2 & & & & & \\
\hline \multirow{3}{*}{ İspanyolca } & \multirow{3}{*}{ DELE } & Nivel B2 & & & & & \\
\hline & & Nivel C1 & $\checkmark$ & & & & \\
\hline & & Nivel C2 & $\checkmark$ & & & & \\
\hline \multirow{3}{*}{ İtalyanca } & \multirow{3}{*}{ CELI } & CELI 3 & $\checkmark$ & $\checkmark$ & $\checkmark$ & & \\
\hline & & CELI 4 & $\checkmark$ & & $\checkmark$ & $\checkmark$ & \\
\hline & & CELI 5 & $\checkmark$ & & & $\checkmark$ & \\
\hline \multirow{3}{*}{ Rusça } & \multirow{3}{*}{ TORFL } & Level 2 & $\checkmark$ & & $\checkmark$ & & $\checkmark$ \\
\hline & & Level 3 & $\checkmark$ & & & & $\checkmark$ \\
\hline & & Level 4 & $\checkmark$ & & $\checkmark$ & & \\
\hline
\end{tabular}

Dil bilgisi bölümü içinde "Sözcük Bilgisi”, "Sözcük Türleri”, "Cümle Kurma”, "Yazım Hatasını Düzeltme”, "Eş-Yakın Anlamlı İfadeler" soruları bulunmaktadır. CELI ve TORFL sınavlarında kısa cevaplı sorular da bulunmaktadır.

TYS'de dil bilgisi başlıklı bir sınav bölümü bulunmamaktadır. Örnek sınavdaki okuma bölümü 1. metnin soruları incelendiğinde boş bırakılan 10 yer için sırasıyla

"1. A) bağlanıyor B) dolanıyor C) geçiyor D) giriyor

2. A) biliniyor B) bekleniyor C) söyleniyor D) rastlaniyor

3. A) düşen $B$ ) gelişen $C$ ) varan D) kavuşan

4. A) bulaşan B) sürülen C) savuran D) karışan

5. A) seviyede B) yükseklikte C) mesafede D) yönde

6. A) kullanışı B) başarılı C) dayanıklı D) güçlü

7. A) hissedilmeyecek B) etkilenmeyecek C) bilinmeyecek D) yayılmayacak 
8. A) üstün B) etkin C) fazla D) büyük

9. A) üstlenirken B) bulurken C) seçerken D) alırken

10. A) tarafindan B) bakımından C) nedeniyle D) hedefiyle". ${ }^{23}$

Sözcüklerden uygun olanın seçilmesi istenmektedir. Öneri sözcükler incelendiğinde farklı türde dil bilgisel sözcükler bulunmaktadır. Bu soru çeşidi, telc ve DELE sınavlarında dil bilgisi bölümlerinde sorulan sözcük bilgisi, sözcük türleri sorularına benzemektedir.

\section{Sonuç ve Tartışma/Conclusions and Discussion}

Bu araştırmanın amacı, Türkçe Yeterlik Sınavı'nı (TYS) uluslararası alanda uygulanan dil yeterlik sınavlarıyla içerik yönünden karşılaştırıp TYS'nin niteliksel görünümünü tespit etmektir.

Araştırmanın bulguları incelendiğinde;

1- TYS ve diğer dil yeterlik sınavları dört beceriye göre hazırlanmıştır. Bununla beraber bazı dil yeterlik sınavlarında dil bilgisi bölümü ve bütünleşik becerilerin ölçüldüğü bölümler de bulunmaktadir.

2- TYS'nin okuma, dinleme, yazma, konuşma sınavlarındaki soru çeşitleri diğer sınavlarda sorulan soru çeşitleriyle aynıdır. Okuma bölümünde grafik okuma soru çeşidinde özgünlük yakalanmıştır. Diğer dil yeterlik sınavlarında sorulup TYS olmayan soru çeşitleri bulunmaktadır. Bu soru çeşitleri okuma sınavında cümle tamamlama, paragraf oluşturma, paragraf tamamlama, eşleştirme, metni özetleme, metni tamamlama, kısa cevaplı sorular, bütünleşik beceri sorularıdır. Dinleme sınavında: izleme metnine bağlı sorular, kısa cevaplı sorular, bütünleşik beceri sorularıdır. Yazma sınavında metindeki hataları düzeltme, özet çıkarma, bütünleşik beceri soruları, grafik yorumlama, metni yeniden yapılandırma sorularıdır. Konuşma sınavında resim veya fotoğraf hakkında konuşma, cümle tekrar etme, veri değerlendirme, telefon görüşmesi yapma, videoyu yorumlama, duygu tonlamalı cümle söyleme (dil ötesi), ikna etme, radyo konuşması yapma, bütünleşik beceri soruları, çoklu aday konuşmasıdır.

3- TYS' de okuma bölümünde örnek çözüm uygulaması yer almazken CPE, CAE, TestDaF, DSD II, telc Deutsch C1, telc Deutsch C2, Goethe-Zertifikat B2, Goethe Zertifikat C1, Goethe-Zertifikat C2 GDS, DELE Nivel C1, DELE Nivel C2, CELI 4, CELI 5 sınavlarının okuma bölümünde örnek çözüm uygulaması bulunmaktadır. Bu uygulama sınavların tamamında olmasa da çoğunda vardır. Dinleme sınavlarındaki örnek çözüm DELE NIVEL B2, Goethe-Zertifikat B2 sınavlarında 1 görevde bulunmaktadır. Dinleme sınavında örnek çözüm uygulaması yaygın değildir.

4- TYS'de dinleme metinleri 1 kez dinletilmektedir. Diğer dil yeterlik sınavlarının dinleme sınavlarında belli görevlerdeki metinler 2. kez dinletilmektedir. TestDaF' ta 1 görev, DSD II'de 1 görev, Goethe-Zertifikat B2'de 1 görev, Goethe-Zertifikat C1'de 1 görev, Goethe-Zertifikat C2 GDS' de 1 görev, DELF B2'de 1 görev, DALF C1'de 1 görev, DELE Nivel B2' de 5 görev, DELE Nivel C1'de 5 görev, DELE Nivel C2'de 4 görev, CELI 3'de 2 görev, CELI 4'de 2 görev, CELI 5 'de 2 görev, dinleme metinlerinin 2 kez dinletildiği sınavlar ve görev sayılarıdır. 
5- Dinleme metinlerinin yazılı hâli fonetik yazısı (transkripsiyonu) TestDaF, DSD II, telc Deutsch B2, telc Deutsch C1, telc Deutsch C2, Goethe-Zertifikat B2, Goethe-Zertifikat C1, Goethe-Zertifikat C2 GDS, DELF B2, DALF C1, DALF C2, DELE Nivel B2, DELE Nivel C1, DELE Nivel C2, TORFL Level 2, TORFL Level 3, TORFL Level 4 örnek sinavlarında bulunmaktayken TYS, CPE, CAE, PTE Akademik, TOEFL iBT, CELI 3, CELI 4, CELI 5 örnek sınavlarında fonetik yazıya (transkripsiyona) rastlanılmamıştır.

6- TYS yazma sınavında 2 görev bulunmaktadır. Bu sayı CPE, CAE, TOEFL iBT, GoetheZertifikat B2, Goethe-Zertifikat C1, Goethe-Zertifikat C2 GDS, DALF C1, DELE Nivel B2, DELE Nivel C1, CELI 3, CELI 4, CELI 5 sinavlarıyla aynıdır. TYS yazma görevlerinde, yazılması istenen sözcük sayısı 325 sözcükle tek sınavlar arasında idealdir.

7- TYS konuşma sınavında adaya 2-3 dakikalık hazırlık süreci verilmektedir. Bu hazırlık süresi DSD II, telc Deutsch, Goethe-Zertifikat, DELF \& DALF, DELE, CELI sinavlarında 15 dakika ile 60 dakika arasında değişmektedir.

8- Konuşma sınavına giren aday sayıları, sınavlara göre değişmektedir. Tek adaylı konuşma sınavları TYS, TOEFL iBT, PTE Akademik, TestDaF, DSD II, telc Deutsch C2, Goethe-Zertifikat C2 GDS, DEFL B2, DALF C1, DALF C2, DELE Nivel B2, DELE Nivel C1, DELE Nivel C2, CELI 3, CELI 4, CELI 5. TORFL Level 2, TORFL Level 3, TORFL Level 4 sinavlarıdır. 2 adaylı konuşma sınavları CPE, CAE, Goethe-Zertifikat B2, Goethe-Zertifikat C1 sınavlarıdır. 3 adaylı konuşma sınavları telc Deutsch B2, telc Deutsch C1 sınavlarıdır. Sınav ortamına göre CPE ve CAE' de de 3 kişi girebilmektedir.

9- TYS' de dil bilgisi bölümü bulunmamaktadır. Dil bilgisi bölümü, dil yeterlik sınavlarının bazılarında ya bağımsız bir bölüm olarak ya da okuma ve dinleme sınavları içerisinde ayrı bir bölüm olarak oluşturulmuştur. CELI VE TORFL sınavlarında dil bilgisi soruları bağımsız bir bölüm olarak soru kitapçığında bulunurken, CPE, CAE, telc Deutsch B2, telc Deutsch C1, DELE Nivel C1, DELE Nivel C2 sınavlarında okuma beceri içerisinde bulunmaktadır. Ayrıca DELE Nivel C1 sınavının Test-2 bölümünde 6 dil bilgisi sorusu dinleme bölümünde sorulmuştur.

\section{5. Öneriler/Suggestions}

1- TYS'deki soru çeşitliliği artırılabilir. İncelenen sınavlarda yer alan sorulardan okuma sınavlarındaki cümle tamamlama, paragraf oluşturma, paragraf tamamlama, eşleştirme, metni özetleme, metni tamamlama, kısa cevaplı sorular, bütünleşik beceri soruları; dinleme sınavlarındaki izleme metnine bağlı sorular, kısa cevaplı sorular, bütünleşik beceri soruları; yazma sınavlarındaki metindeki hataları düzeltme, özet çıkarma, bütünleşik beceri soruları, grafik yorumlama, metni yeniden yapılandırma soruları; konuşma sınavlarındaki resimfotoğraf-video yorumlama, cümle tekrar etme, veri değerlendirme, telefon görüşmesi yapma, radyo konuşması yapma, çoklu aday konuşması, dil ötesi beceri soruları benzer ya da farklı şekilde TYS' de yer alabilir. 
2- TYS' de, diğer dil yeterlik sınavlarında olduğu gibi okuma ve dinleme sınavında 1 örnek çözüm uygulaması bulunabilir.

3- Dinleme sinavındaki metinler 2. kez dinletilebilir.

4- Dinleme metinlerinin yazılı hâli fonetik yazısı (transkripsiyonu) örnek sorularla beraber paylaşılabilir.

5- Konuşma sınavındaki hazırlık süresi artırılabilir. Soru içerikleriyle bağlantılı olarak hazırlık süresi sınav süresine eşit olabilir. 15 dakika hazırlık süresi, 15 dakika sınav süresi olabilir.

6- Yazma sınavına ait sorular paylaşıldığı gibi bu sorulara verilen örnek cevap metinleri de paylaşılabilir.

Hakem Değerlendirmesi: Dış bağımsız.

Çıkar Çatışması: Yazarlar çıkar çatışması bildirmemiştir.

Finansal Destek: Yazarlar bu çalışma için finansal destek almadığını beyan etmiştir.

Peer-review: Externally peer-reviewed.

Conflict of Interest: The authors have no conflict of interest to declare.

Grant Support: The authors declared that this study has received no financial support.

\section{Kaynaklar/References}

Cambridge.“Cambridge Proficiency English”. Retrieved November 5, 2018. https:/www.cambridgeenglish. org/exams-and-tests/proficiency/.

Cambridge."Cambridge Advanced English”. Retrieved November 5, 2018. https://www.cambridgeenglish. org/exams-and-tests/advanced/.

Cervantes. “Diplomas de Espanol Como Lengua Extranjera”. Retrieved January 23, 2018. https://examenes. cervantes.es/es/dele/examenes.

CIEP. “Diplôme D’études En Langue Française / Diplôme Approfondi En Langue Française”. Retrieved January 25, 2018.

http://www.ciep.fr/en

Council of Europe. "Common European Framework of Reference for Languages: Learning, Teaching, Assessment. Companion Volume with New Descriptors." Language Policy Programme, Education Policy Division, Education Department. 2018.

ETS. “Test of English as a Foreign Language Internet Based Test”. Retrieved January 25, 2018. https://www.ets.org/.

Goethe. “Goethe-Zertifikat”. Retrieved January 25, 2018. https://www.goethe.de/de/index.html.

Köse, Dursun. “Türkçenin Yabancı Dil Olarak Öğretiminde Sınavların Hazırlanması ve Uygulanması.”, Ankara Üniversitesi Dil Dergisi 139 (2008): 36- 47.

Maden Sedat, Dincel Ömer, ve Maden Aslı. "Türkçeyi Yabancı Dil Olarak Öğrenenlerin Yazma Kaygıları." Uluslararası Türkçe Edebiyat Kültür Eğitim (TEKE) Dergisi 4(2) (2015): 748-769. DOI: 10.7884/teke.488 
MEB. Diller İçin Avrupa Ortak Başvuru Metni Öğrenme-Öğretme-Değerlendirme. Ankara: Talim Terbiye Kurulu Başkanlığı Yayınları, 2009.

Pearson. "Pearson Test of English Academic". Retrieved July 26, 2018. https://tr.pearson.com/tr.html.

Perugia. “Certificato Di Lingua Italiana”. Retrieved January 25, 2018. https://www.cvcl.it/categorie/categoria64? explicit=SI.

Pushkin. "Test of Russian as a Foreign Language". Retrieved January 25, 2018. http://www.pushkin.institute/ Certificates/CGT/ekzameny-v-sisteme-trki.php.

ÖSYM. "Yabancı Dil Sınavları Eşdeğerlikleri”. Erişim Tarihi Şubat 25, 2016. https://www.osym.gov.tr/ TR,10220/yabanci-dil-sinavlari-esdegerlikyonergesi- ve-esdegerlik-tablosu-26022016.html.

Telc. Diller İçin Avrupa Ortak Öneriler Çerçevesi -Öğrenim, Öğretim ve Değerlendirme [Common European Framework of Reference for Languages - Learning, Teaching and Assessment]. Frankfurt, Germany: Telc $\mathrm{GmbH}, 2013$.

Telc. "The European Language Certificates”. Erişim Tarihi 26 Temmuz, 2018.

https://www.telc.net/tr/sinav-katilimcilari/dil-sinavlari.html.

TestDaF. “Der Test Deutsch als Fremdsprache”. Retrieved January 26, 2019. https://www.testdaf.de/.

YEE. “Türkçe Yeterlik Sınavı”. Erişim Tarihi 8 Ocak, 2018.

https://tys.yee.org.tr/

Yıldırım Ali, Şimşek Hasan. Sosyal Bilimlerde Nitel Araştırma Yöntemleri. (11. Baskı), Ankara: Seçkin Yayınc1lik, 2018.

ZfA. "Deutsches Sprachdiplom II". Retrieved July 26, 2018. https://www.bva.bund.de/SharedDocs/ Organisationseinheiten/DE/Abteilung_ZfA/Abteilung_ZfA.html. 


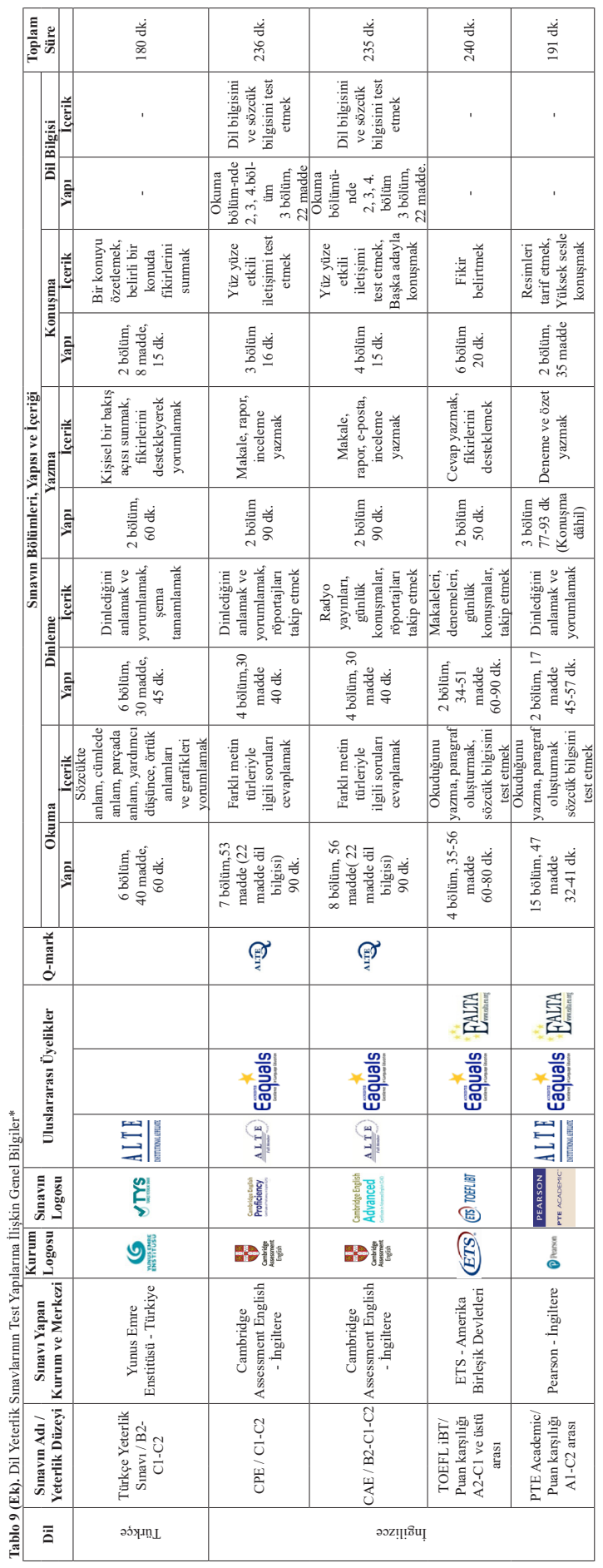




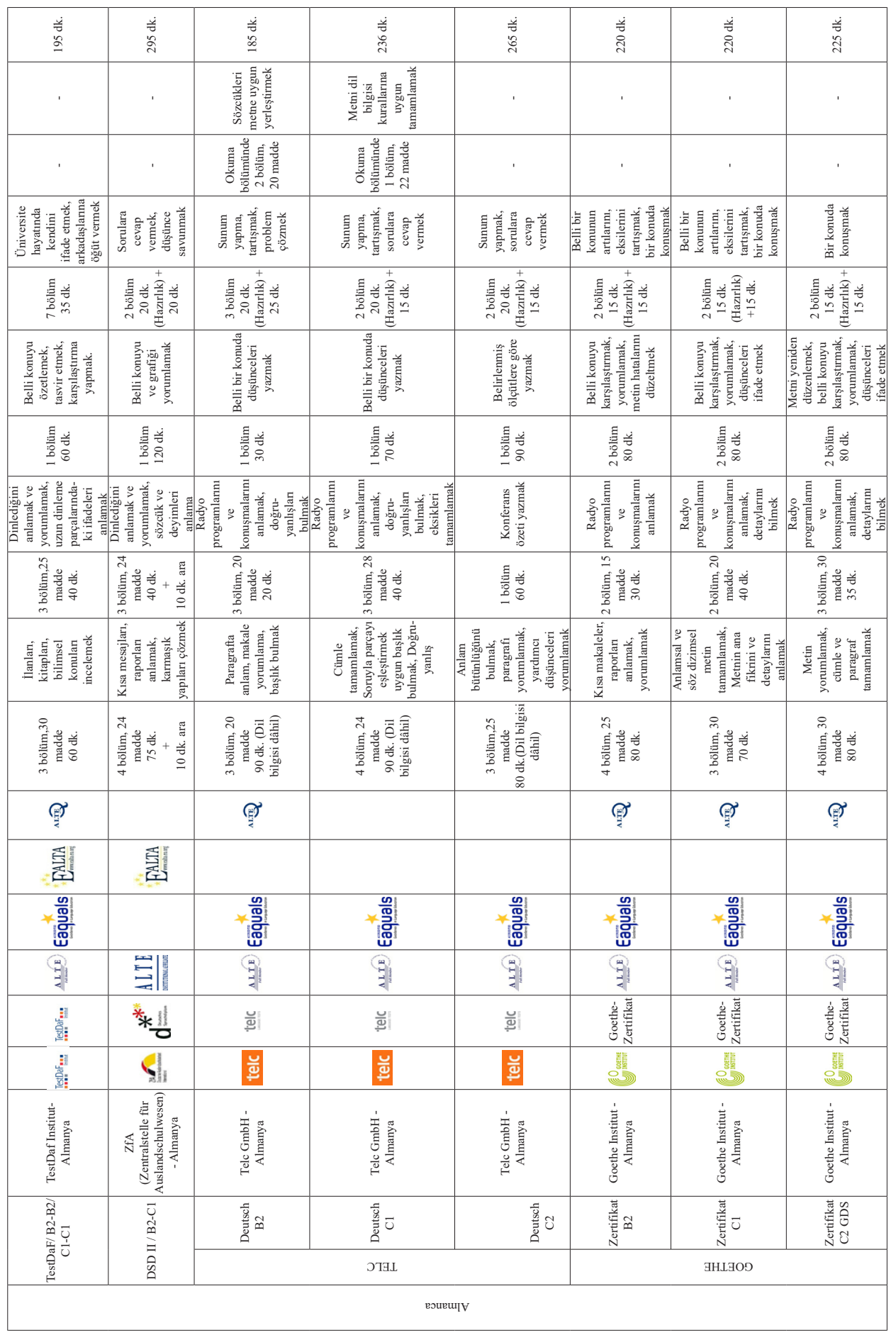




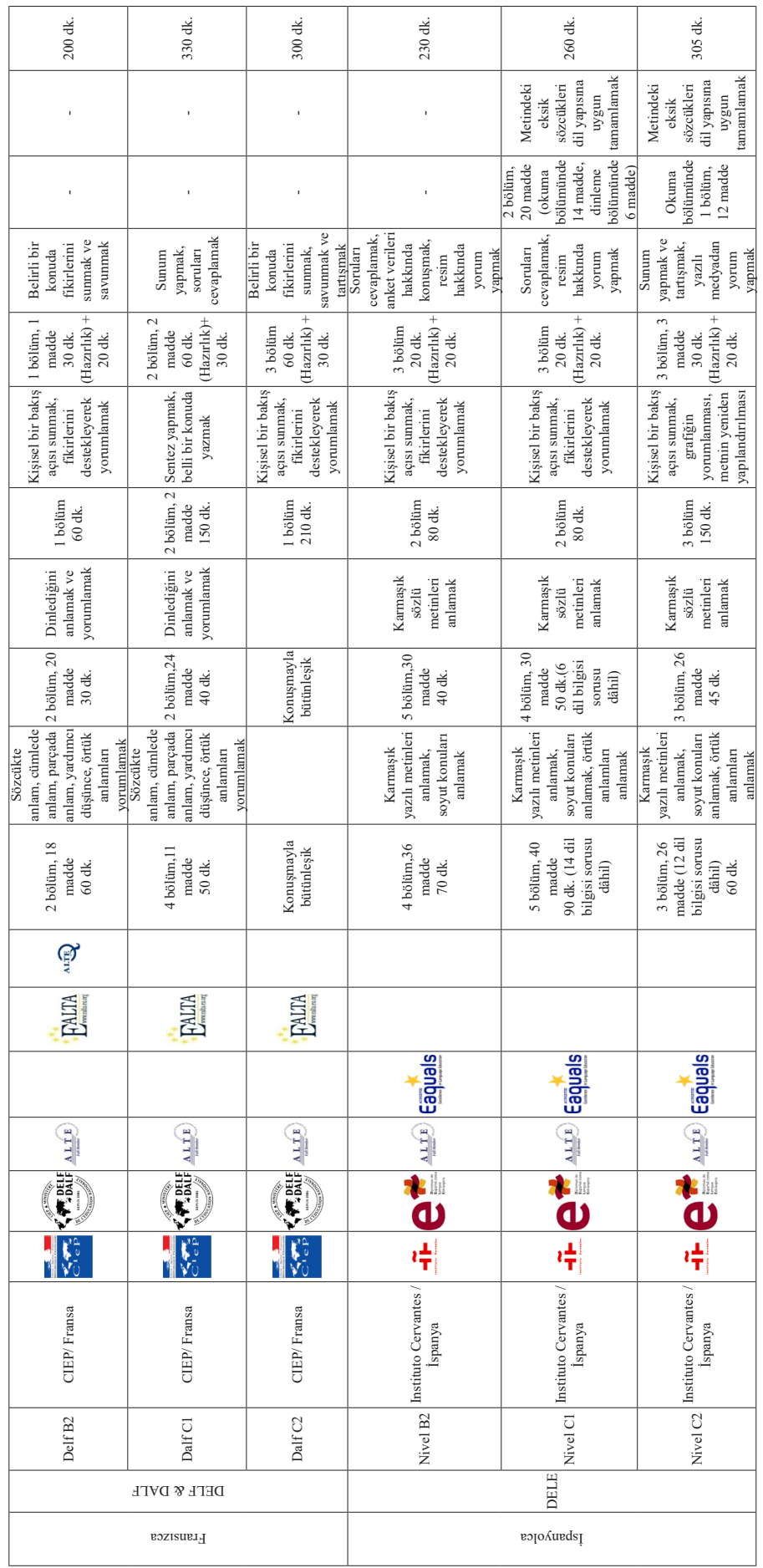




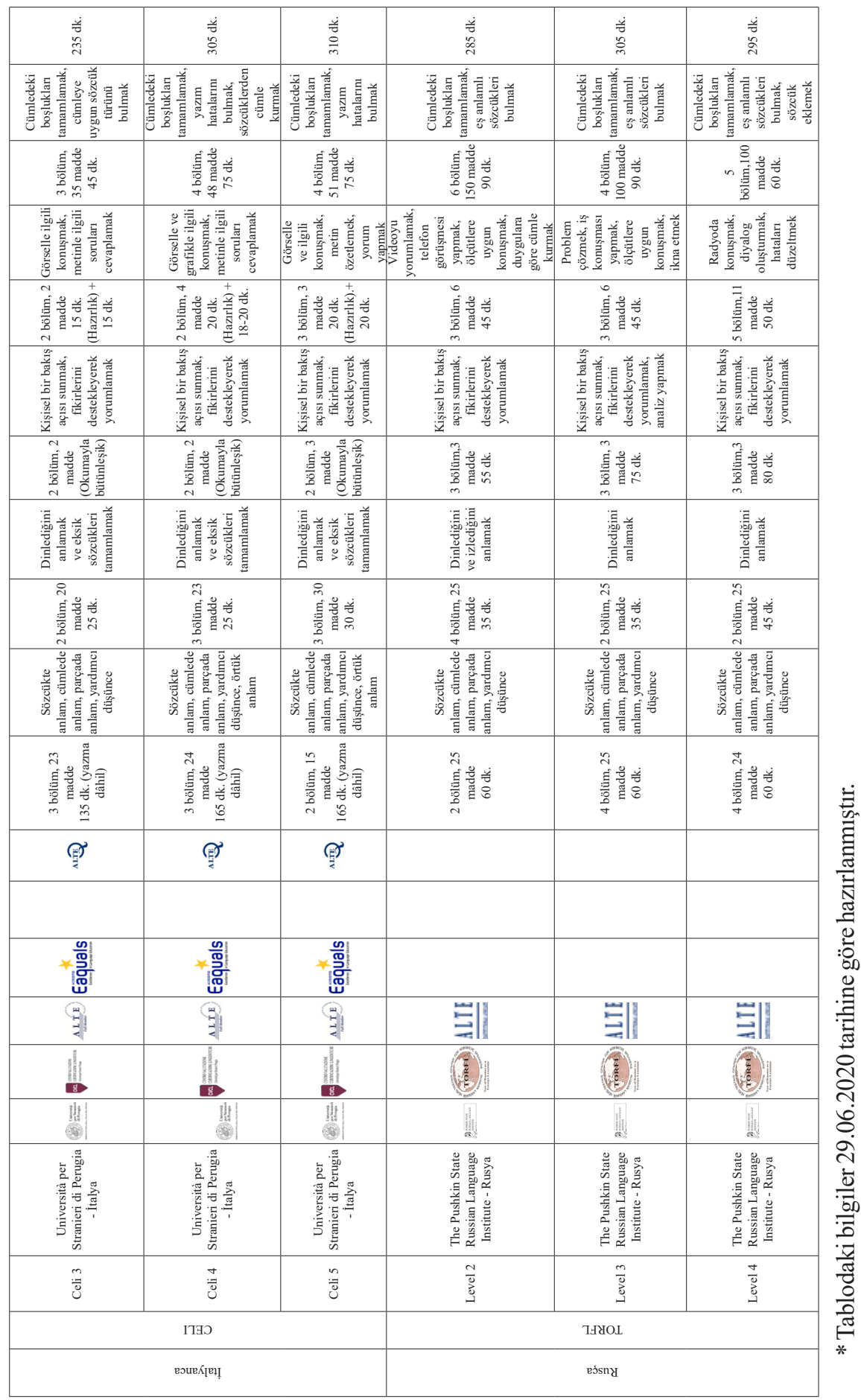

